\title{
Pengembangan Budaya Keselamatan dan Kesehatan Kerja Melalui Peningkatan Keterampilan Pemadaman Kebakaran bagi Pekerja di Objek Wisata Tebing Breksi, Kabupaten Sleman
}

\author{
Machfudz Eko Arianto ${ }^{1}$, Helfi Agustin ${ }^{2}$, Muchamad Rifai ${ }^{3}$, \\ Universitas Ahmad Dahlan, Kota Yogyakarta, Indonesia ${ }^{1,2,3}$ \\ e-mail: $\underline{\text { machfudz.arianto@ikm.uad.ac.id }}{ }^{1}{ }^{*}$ Helfi.Agustin@ikm.uad.ac.id ${ }^{2}$ \\ Muchamad.Rifai@ikm.uad.ac.id ${ }^{3}$ \\ *Coresponding Author
}

Submited: May 22, 2021; Revised: June 22, 2021; Accepted: July 22, 2021; Published: November 12, 2021

\begin{abstract}
ABSTRAK
Pariwisata termasuk tempat usaha yang sangat rentan mengalami keterpurukan pada saat terjadi bencana seperti pandemic atau bencana lainnya. Pandemi covid-19 adalah kasus kesehatan masyarakat yang paling actual di tempat wisata, namun pariwisata di Indonesia telah memiliki masalah kesehatan masyarakat jauh sebelum pandemi Covid-19. Beberapa masalah yang sering muncul namun sifatnya kasuistik adalah penyakit diare, hepatitis $A$, malaria, DBD, HIV/AIDS. Selain itu masalah kecelakaan dan kebakaran di tempat wisata juga berdampak terhadap reputasi pariwisata. Pada bulan Agustus 2017 terjadi kebakaran di kawasan wisata dekat Pantai Carita Pandeglang. Pengabdian ini bertujuan memberikan edukasi kepada pengelola wisata tentang cara pemadaman kebakaran. Metode yang digunakan adalah metode Ceramah (teori) dan Praktik. Hasil yang didapatkan seluruh peserta belum paham cara memadamkan kebakaran dengan menggunakan APAR dan karung goni. Intervensi yang dilakukan saat pengabdian yaitu berupa pelatihan dengan pemberian teori dan praktik, hal ini dilakukan supaya pengetahuan dan keterampilan tentang pemadaman kebakaran menjadi lebih baik.
\end{abstract}

Kata kunci : 1) Kebakaran 2) Keselamatan dan Kesehatan Kerja 3) Pariwisata

\section{ABSTRACT}

Tourism is a place of business that is very vulnerable to experiencing a downturn in the event of a disaster such as a pandemic or other disaster. The COVID-19 pandemic is the most actual public health case in tourist attractions, but tourism in Indonesia had public health problems long before the Covid-19 pandemic. Some problems that often arise but are casuistic in nature are diarrhea, hepatitis A, malaria, DHF, HIV/AIDS. In addition, the problem of accidents and fires in tourist attractions also has an impact on the reputation of tourism. In August 2017 a fire broke out in a tourist area near Carita Pandeglang Beach. This service aims to educate tourism managers about how to extinguish fires. The method used is the Lecture method (theory) and Practice. The results obtained by all participants have not seen how to fire fires by using fire extinguishers and burlap. Interventions carried out during service are in the form of training by providing theory and practice, this is done so that knowledge and skills about fire fighting become better.

Keywords : 1) Fire 2) Occupational Health and Safety 3) Tourism

Copyright (C) 2021 The Author(s)

This is an open access article under the CC BY-SA license. 


\section{PENDAHULUAN}

Pariwisata di Indonesia saat ini berkembang pesat dan menjadi kebutuhan bagi masyarakat. Jumlah kunjungan wisatawan mancanegara ke Indonesia periode Januari s.d. Desember 2016 secara kumulatif sebanyak 12.023.971 kunjungan. Sementara itu, jumlah perjalanan wisatawan nusantara telah mencapai 263,68 juta perjalanan, dari target 260 juta perjalanan.

Berbagai obyek wisata alam maupun buatan yang disediakan oleh pengelola tempat wisata tidak memberikan jaminan keamanan dan keselamatan pengunjung sepenuhnya (Gössling et al, 2020). Berdasarkan Undang - Undang Nomor 10 Tahun 2009 tentang Kepariwisataan, hak wisatawan antara lain yaitu memperoleh perlindungan hukum dan keamanan serta perlindungan asuransi untuk kegiatan pariwisata yang berisiko tinggi.

Pariwisata termasuk tempat usaha yang sangat rentan mengalami keterpurukan pada saat terjadi bencana seperti pandemic atau bencana lainnya. Pandemi covid-19 adalah kasus kesehatan masyarakat yang paling actual di tempat wisata, namun pariwisata di Indonesia telah memiliki masalah kesehatan masyarakat jauh sebelum pandemi Covid-19. Beberapa masalah yang sering muncul namun sifatnya kasuistik adalah penyakit diare, hepatitis $A$, malaria, DBD, HIV/AIDS(McA Baker, 2015), masalah kebakaran di restoran, dan kecelakaan transportasi saat berwisata yang dapat berdampak kurang baik kepada pariwisata (Armutlu et al, 2020). Selain permasalahan Kesehatan, ada pula permasalahan keselamatan yaitu kejadian kebakaran.

Menurut Pusat Penanggulangan Krisis Kesehatan Kementerian Kesehatan RI (PPKK), bencana non alam tahun 2016 yang paling sering terjadi di Indonesia salah satunya adalah kebakaran (20\%). Bencana kebakaran juga sering terjadi di kawasan wisata. Beberapa kasus kebakaran yang terjadi di tempat wisata pada bulan Agustus 2017 antara lain di kawasan wisata dekat Pantai Carita Pandeglang, terjadi kebakaran yang menghabiskan 17 rumah semipermanen (Rifa'i, 2017).

Objek wisata tebing breksi memiliki potensi bahaya kebakaran, potensi tersebut muncul dari aktivitas memasak. Oleh karena itu pihak manajemen tebing breksi menyediakan fasilitas berupa Alat Pemadaman Api Ringan (APAR), akan tetapi banyak dari pengelola belum paham bagaimana menggunakan APAR tersebut. Olehkarena itu tim pengabdian dari Fakultas Kesehatan Masyarakat, Universitas Ahmad Dahlan, memfasilitasi pengelola objek wisata tebing breksi terkait dengan pelatihan pemadaman kebakaran

\section{METODE}

Desain studi yang digunakan pada pelaksanaan pengabdian kepada masyarakat yaitu memberikan teori dan praktik tentang pemadaman kebakaran. Sebelum memberikan teori dan praktik, tim pengabdian terlebih dahulu memberikan kuesioner pre test untuk mengetahui tingkat pengetahuan pengelola tentang pemadaman kebakaran. Kemudian setelah pemberian teori dan praktik, dilanjutkan dengan Pos test.

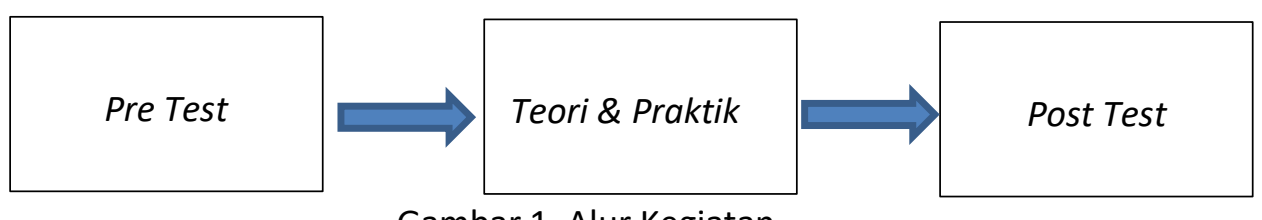

Gambar 1. Alur Kegiatan 


\section{HASIL DAN PEMBAHASAN}

Kegiatan pelatihan merupakan salah satu bentuk kegiatan pengabdian kepada masyarakat. Kegiatan ini dilakukan dengan cara membekali pengelola objek wisata tebing breksi dengan kemampuan teori dan praktik pemadaman kebakaran. Kegiatan pelatihan ini diikuti oleh 20 peserta dan dibuka secara langsung oleh pimpinan atau ketua pengelola objek wisata tebing breksi.

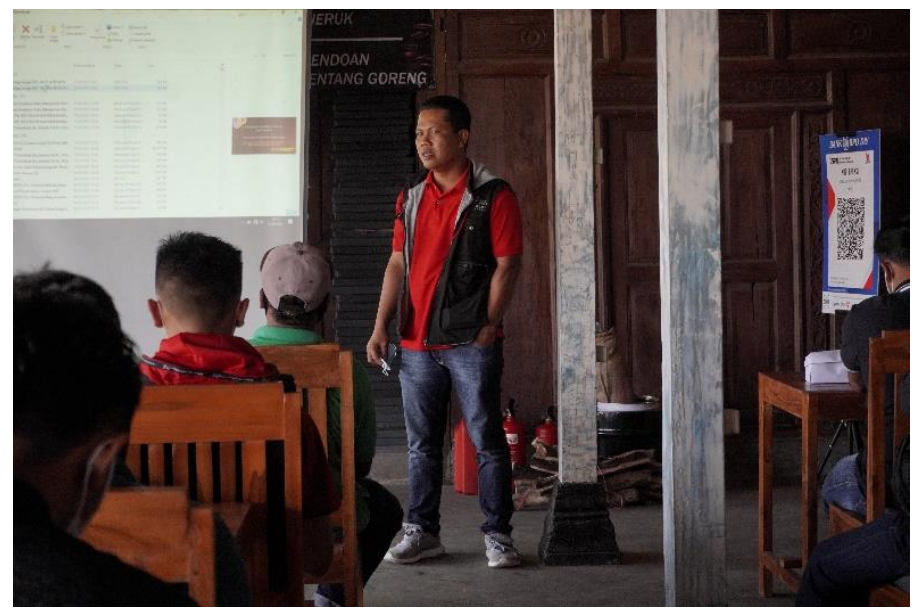

Gambar 2. Sambutan oleh Pimpinan Pengelola objek wisata tebing breksi
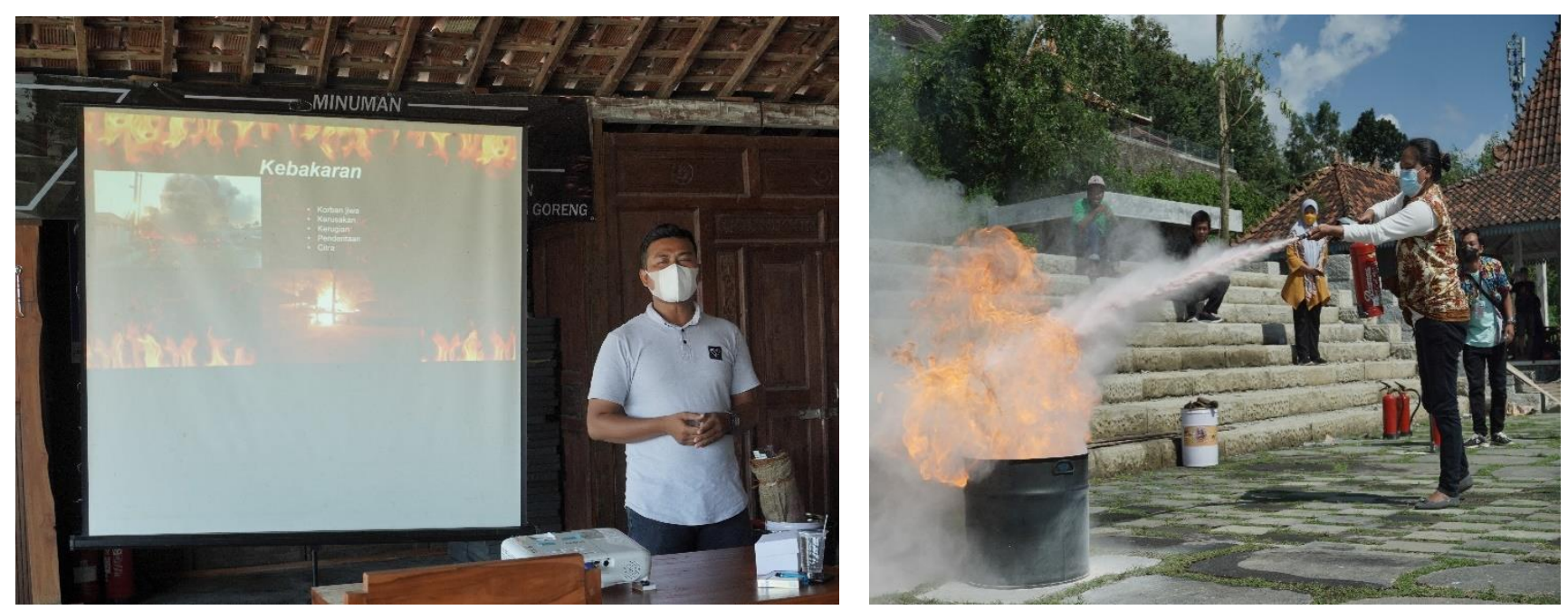

Gambar 3. Pemberian teori dan Praktik

Hasil pre test terkait pengetahuan pemadaman kebakaran didapatkan skor mean pengetahuan sebelum dilakukan intervensi sebesar 60,00 sedangkan skor mean pengetahuan sesudah dilakukan intervensi sebesar 62,86 yang berarti secara rata-rata nilai post tes lebih 
tinggi -2.857 poin dibandingkan nilai pre test, akan tetapi tidak bermakna secara statistik ( $\mathrm{p}$ value $=0,703$ ). Adapun hasil pre dan post test pengetahuan ditampilkan pada Gambar 4

\section{PENGETAHUAN SEBELUM DAN SESUDAH DIBERIKAN PELATIHAN}

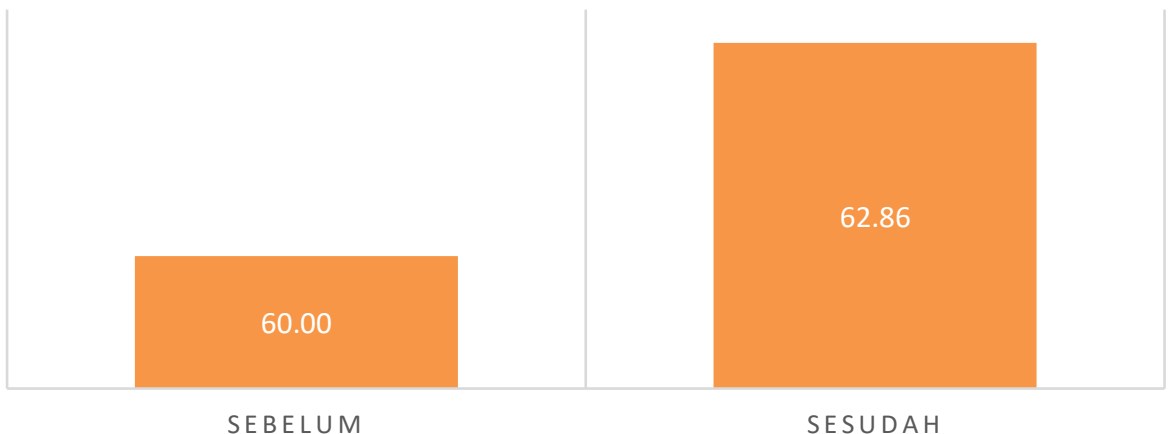

Gambar 4. Grafik Pengetahuan sebelum dan sesudah Pelatihan

Menurut Kaswan (2011), "Pelatihan adalah proses meningkatkan pengetahuan dan keterampilan karyawan." Menurut Nugroho (2017) Pelatihan mempunyai manfaat jangka panjang yang membantu pekerja memiliki tanggung jawab yang lebih besar di waktu yang akan datang. Pelatihan merupakan upaya untuk mengembangkan sumber daya manusia, terutama untuk mengembangkan kemampuan intelektual dan kepribadian. Pelatihan juga merupakan bagian dari suatu proses pendidikan yang bertujuan untuk meningkatkan kemampuan dan keterampilan khusus seseorang atau sekelompok orang (Hariandja, 2002).

Pengabdian ini merupakan salah satu bentuk dalam upaya meningkatan pengetahuan dan keterampilan pekerja, jika terjadi emergency pekerja bisa atau dapat menggunakan APAR untuk memadamkan api. Metode yang digunakan adalah ceramah dan presentasi video, serta praktik. Ceramah dan presentasi video digunakan karena menawarkan sisi ekonomis dan partisipasi dapat meningkat dengan adanya diskusi selama ceramah. Sedangkan praktik dirancang untuk meningkatkan keterampilan interpersonal. Juga dapat digunakan untuk membangun perilaku yang diinginkan untuk tanggung jawab pekerjaan dimasa depan (Rivai, 2009).

Terjadinya peningkatan pengetahuan pada pengabdian ini karena tim pengabdi menggabungkan dua metode dalam pelatihan, selain itu tim pengabdi mempersiapkan dengan sangat matang segala bentuk media sarana prasarana pelatihan berupa materi, APAR, karung goni, dan lainnya. Media sangat berperan penting dalam peningkatan pengetahuan pekerja tentang penggunaan APAR. Fungsi media dalam pendidikan adalah sebagai alat peraga untuk menyampaikan informasi atau pesan-pesan tentang kesehatan (Notoatmodjo, 2014). Hal ini didukung oleh pendapat Rusman (2013), media pembelajaran memiliki fungsi yang sangat strategis dalam pembelajaran. Beberapa fungsi media dalam pembelajaran, yaitu sebagai alat bantu dalam proses belajar mengajar. Media merupakan alat bantu yang dapat memperjelas, mempermudah, mempercepat penyampaian pesan atau materi pelajaran kepada para peserta, 
sehingga inti materi pelajaran secara utuh dapat disampaikan, sebagai komponen dari sub sistem pembelajaran.

Menurut Simamora dalam Hartatik (2014) terdapat beberapa manfaat yang didapat dari program pelatihan, yaitu sebagai berikut: a. Meningkatkan kuantitas dan kualitas produktivitas. b. Mengurangi waktu belajar yang diperlukan karyawan untuk mencapai Standar kinerja yang dapat diterima c. Membentuk sikap, loyalitas, dan kerja sama yang lebih Menguntungkan d. Memenuhi kebutuhan pertencanaan sumber daya manusia. e. Mengurangi frekuensi dan biaya kecelakaan kerja. f. mengembangkan pribadi karyawan

\section{SIMPULAN}

Berdasarkan hasil kegiatan pengabdian kepada masyarakat yang telah dilakukan dapat disimpulkan Bahwa terjadi peningkatan pengetahuan cara penggunaaan APAR sesudah diberi pelatihan. Secara umum pelaksanaan PPM berjalan dengan lancar.

\section{UCAPAN TERIMA KASIH}

Penulis mengucapkan terimakasih kepada Lembaga Penelitian dan Pengabdian Kepada Masyarakat, Universitas Ahmad Dahlan yang telah mendukung kegiatan program pengabdian kepada masyarakat, sehingga program ini dapat berjalan dengan lancar dan sesuai yang diharapkan.

\section{DAFTAR REFERENSI}

Armutlu ME, Bakır AC, Sönmez H, Zorer E, Alvarez MD. Factors affecting intended hospitable behaviour to tourists: hosting Chinese tourists in a post-Covid-19 world. Anatolia [Internet]. 2020;00(00):1-14. Available from: https://doi.org/10.1080/13032917.2020.1855595

Gössling S, Scott D, Hall CM. Pandemics, tourism and global change: a rapid assessment of COVID-19. J Sustain Tour [Internet]. 2020;29(1):1-20. Available from: https://doi.org/10.1080/09669582.2020.1758708

Hariandja, Marihat Tua Efendi, 2002, "Manajemen Sumber Daya Manusia”, Grasindo, Jakarta.

Hartatik, I.P. (2014). Buku Praktis Mengembangkan SDM (Cetakan ke-1). Yogyakarta: Laksana

Kaswan M. M 2011. Pelatihan dan Pengembangan Untuk Meningkatkan Kinerja SDM. Bandung CV Alfabeta

McA Baker D. Tourism and the Health Effects of Infectious Diseases: Are There Potential Risks for Tourists? International Journal of Safety and Security in Tourism/Hospitality Tourism and the Health Effects of Infectious Diseases: Are There Potential Risks for Tourist. Int J Saf Secur Tour. 2015;12.

Notoatmodjo, S. 2014. IImu \& Seni Kesehatan Masyarakat. Jakarta: Rineka Cipta. Hal. 118

Nugroho F.A. 2017. Pengaruh Budaya Organisasi, Kepemimpinan, dan Motivasi Kerja Terhadap Kinerja Karyawan Pada PT. Bank Danamon Devisi Semm Area Ngawi. Jurnal Bidang IImu Ekonomi Volume. 12 No. 2. Di akses pada 15 Maret 2019. 
Rifa'i. Kebakaran di Kawasan Wisata Pantai Carita, 17 Rumah Ludes Terbakar.

https://news.detik.com/berita/d-3645483/kebakaran-di-kawasan-wisata-pantai-carita17-rumah-ludes-terbakar. Diakses 09/11/2021

Rivai, Veithzal. 2009. Manajemen Sumber Daya Manusia Untuk Perusahaan Dari Teori ke Praktik. Jakarta: Raja Grafindo Persada

Rusman, 2013. Belajar dan Pembelajaran Berbasis Komputer. Bandung: Alfabeta.

Undang - Undang Nomor 10 Tahun 2009 tentang Kepariwisataan 